\title{
Journal of Pharmacy
}

\section{Human immunodeficiency virus (HIV)/ acquired immunodeficiency syndrome (AIDS): knowledge, perception, and attitude among pharmacists in Kelantan, Malaysia.}

\author{
Muhammad Munzir Sidi Omar ${ }^{*}$, Nur Amalina Wahida Ab Wahab¹, Ong Ann Gie, Nurul Izyan \\ Mohamed Azam¹, Aqilah Muhammad ${ }^{1}$ and Siti Nor Asiah Ab Ghani ${ }^{1}$
}

\section{ABSTRACT}

Introduction: Although pharmacists' role in the care of human immunodeficiency virus (HIV)infected and acquired immunodeficiency syndrome (AIDS) patients is well established, studies had reported pharmacists' negative attitudes towards people living with HIVIAIDS (PLWHA), with negative impact on HIV management. This study aimed to explore pharmacists' knowledge of HIVIAIDS, perception towards the changing of treatment regimens of HIVIAIDS, attitudes towards PLWHA, and to identify factors affecting the pharmacists' attitudes towards PLWHA in the state of Kelantan, which reportedly have the third highest number of HIVIAIDS patients in Malaysia.

Materials and method: A validated online 43-item questionnaire was distributed to 400 pharmacists in Kelantan. Multivariate logistic regression was performed to identify factors associated with pharmacists' negative attitude towards PLWHA.

Results: A total of 170 respondents (response rate $42 \%$ ) completed the questionnaire. Respondents had knowledge on the potential causes of HIV infection [median (IQR) score=13.00(1); maximum score $=14.00$ ], and preventive measures of HIVIAIDS transmission [median (IQR) score $=12.00(1)$; maximum score $=12.00]$. On decision in changing regimens, the respondents agreed on the need to change treatment regimen for HIVIAIDS when required [median (IQR) score $=7.00(2)$; maximum score $=8.00]$. Up to $40.6 \%$ of respondents thought that the treatment regimen should not be switched based on cost. Two-thirds of the respondents had negative attitudes towards PLWHA (67.1\%). Respondents who worked in community pharmacy reported positive attitudes towards PLWHA (Adj OR=0.125; 95\% Cl=0.025-0.623; $p=0.011$ ).

Conclusion: Pharmacists in Kelantan had several misconceptions towards the causes of HIVIAIDS, preventive measures of HIVIAIDS transmission, and necessity in changing treatment regimen when required. Despite good disease related knowledge, most pharmacists had negative attitudes towards PLWHA, while pharmacists working in community settings presented more positive attitudes towards PLWHA.

\section{ARTICLE HISTORY:}

Received: 18 August 2020

Accepted: 11 November 2020

Published: 8 January 2021

\section{KEYWORDS:}

Pharmacists, people living with human immunodeficiency virus/acquired immunodeficiency syndrome (PLWHA), knowledge, perception, attitude.

\section{HOW TO CITE THIS ARTICLE:}

Sidi Omar, M. M., Ab Wahab, N. A. W., Ong, A. G., Mohamed Azam, N. I., Muhammad, A. \& Ab Ghani, S. N. A. (2021). Human immunodeficiency virus (HIV)/acquired immunodeficiency syndrome (AIDS). Journal of Pharmacy, 1(1), 8-18.

\section{${ }^{*}$ Corresponding author:}

Email address: munzir66@yahoo.com Tel:+6013 4579535

\section{Authors' Affiliation:}

${ }^{1}$ Unit of Pharmacy, Hospital Tanah Merah, 17500 Tanah Merah, Kelantan, Malaysia

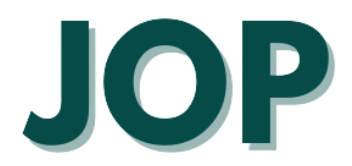




\section{Introduction}

Human immunodeficiency virus (HIV) remains a major global public health issue. Approximately 36.9 million people globally (World Health Organisation, 2019), and 87,122 people in Malaysia was living with HIV (Ministry of Health Malaysia, 2018) in 2017. Almost 33 million lives were claimed by HIV infection by 2019 . However, with the increasing efforts by the healthcare sector in HIV prevention and treatment, the infection has become a manageable chronic health condition (World Health Organisation, 2019). Since 2015, Malaysia has adopted the vision of World Health Organisation (WHO) in the new National Strategic Plan in Ending AIDS 2016-2030 to end the acquired immune deficiency syndrome (AIDS) epidemic as a public health threat by year 2030, with the goal of "Three Zeros: Zero new HIV infections, zero HIV-related deaths and zero HIV-related discrimination" (Ministry of Health Malaysia, 2015).

Antiretroviral therapy (ART) is the main treatment in management of HIV infection. High levels of adherence towards ARTs of greater than $95 \%$ is needed to adequately suppress HIV-viral replication, produce long-lasting response, and halt disease progression (Paterson et al., 2000). Poor patient and health care providers relationship was found to be among one of the significant causes of poor adherence to ART (Schaecher, 2013). Involvement of pharmacists in the care of people living with HIV/AIDS (PLWHA) has been proven to be associated with better treatment outcomes through ART adherence enhancement and pill burden reduction, resulting in improved CD4 cell counts, rates of viral suppression, and reduced medication errors (Tseng et al., 2012).

HIV-related discrimination is defined as the act of treating PLWHA differently than those without HIV; while HIV stigma is defined as the negative beliefs, feelings, and attitudes towards PLWHA (Centers for Disease Control and Prevention, 2019). HIV-related stigma and discrimination is a recognised barrier in combating HIV burden. In Thailand, it was found that PLWHA were being denied health care services, provided with poor quality and delayed care, and were treated discriminatorily with violated rights due to the HIV-related stigmatization and discrimination (Pudpong et al., 2014). These negative experiences may hinder PLWHA to seek or to access healthcare services.

In Malaysia, pharmacists play significant roles in providing education and counselling to PLWHA. In clinical settings, specialised medication therapy adherence clinics run by pharmacists were set up to monitor therapy adherence and outcomes, assess medication-related issues, and provide quality services for PLWHA (Pharmaceutical Services Division Ministry of Health Malaysia, 2014). Although pharmacists' involvement in HIV-positive patients care is well-established and recognised, one study conducted among hospital pharmacists in Kedah, Malaysia reported that hospital pharmacists had negative attitudes towards PLWHA (Khan \& Baig, 2013). This may indicate hindrance towards health-care accessibility of PLWHA which can further impair the Ministry of Health's efforts to curb the disease. However, these findings may not be generalised to Kelantan, a different state in Malaysia with the third most HIV case prevalence (10.3\%). Distribution of HIV-positive cases were lower in Kedah (6.1\%) (Ministry of Health Malaysia, 2018), and the pharmacists' exposure and awareness towards HIV may be lesser.

In addition, the population and cultural distribution of Kedah and Kelantan is very different. In terms of ethnicity groups, Kedah consists of $78 \%$ Malays, $13.6 \%$ Chinese, and 7.2\% Indians; while Kelantan consists $95.6 \%$ Malays, 3.4\% Chinese, and $0.3 \%$ Indians (City Population, 2017). These significant differences between the states may lead to differences in cultural beliefs which may further affect attitude towards PLWHA. Furthermore, since the initiation of WHO's National Strategic Plan in Ending AIDS in 2015, there has been increased educational activities to promote awareness and reduce HIV-stigma in the recent years (Ministry of Health Malaysia, 2015). Therefore the findings by Khan and Baig (2013) may not reflect the current scenario among pharmacists in Malaysia. Hence, this study was conducted to explore pharmacists' knowledge towards HIV/AIDS, perceptions towards changing of treatment regimen in HIV/AIDS, attitudes towards PLWHA, and investigate the factors affecting pharmacists' attitudes towards PLWHA in the state of Kelantan, Malaysia.

\section{Methodology}

\section{Study design and study process}

This cross-sectional self-administered online questionnaire-based study was conducted among pharmacists who worked in Kelantan, Malaysia. Ethical approval was obtained from the Ministry of Health Medical Research Ethics Committee (NMRR-19-26-45683). All fully registered pharmacists and provisionally registered pharmacists who practiced in Kelantan were recruited. Pharmacists who were non-Malaysian, retired, and on study leaves were excluded. The samples were included by using convenience sampling.

Emails of pharmacists who worked in Kelantan were obtained through Pharmaceutical Services Division of Kelantan with permission. Softcopies of formal invitations were distributed through valid emails to 400 pharmacists. Emails were not sent to pharmacists who had no record of emails or with invalid emails, and pharmacists who met the exclusion criteria. Two reminder emails were sent on two weeks intervals to increase the number of participants. Participation by pharmacists into this study was voluntary.

After informed consent form was signed, study participants were required to fill in respective pharmacist's registration number as a measure to ensure that only 
pharmacists were included into this study, and to avoid duplication of responses. Instructions on filling the questionnaire were provided at the start of the questionnaire. All questions were displayed in the online questionnaire. For open-ended questions, participants were required to type in their answers. For closed-ended questions, participants were required to choose only one answer from the options displayed. The participants were required to answer all the questions before submitting the questionnaire. All the data were synchronised into a password-protected online subject data sheet automatically.

\section{Study sample}

Traced data from Pharmaceutical Services Division of Kelantan had shown that there were 334 pharmacists working in government facilities, 109 pharmacists working in private sectors, and 40 pharmacists working in academic institution. By using Raosoft ${ }^{\circledR}$ Sample Size Calculator, assuming the margin of error $=5 \%$; confidence level $=95 \%$; population size $=483$; and response distribution $=50 \%$, the minimum sample size required was 215.

\section{Study instrument}

Permission for the adoption of the validated questionnaire was obtained from Khan and Baig (2013). The questionnaire was developed into an online questionnaire. The questionnaire consisted of six sections. Compared to the questionnaire by Khan and Baig (2013), collection of demographic data were modified to include academic qualifications and place of practice, and to exclude marital status. There were no modifications done on the questionnaire from section two to section six, which consisted of 43-items. A pilot test was carried out among 20 pharmacists working in other states of Malaysia. Respondents who were involved in the pilot study were not included in this study sample.

Section one was designed to obtain the respondents' demographic information including age, gender, race, academic qualification, job experience, number of HIV encountered in the past twelve months, and place of practice. Section two was designed to assess respondents' general knowledge regarding HIV/AIDS. Three open-ended questions were included in this section, including "What does the abbreviation of AIDS stands for?", "Is HIV a transmittable disease?", and "Can HIV/AIDS be cured at this moment?".

Nominal scale "Yes/No" was applied for the respondents to answer the statements from sections three and four. Section three was designed to assess respondents' knowledge towards the causes of HIV/AIDS, which consisted of 14 items. "Yes" were the correct answers for statements one to eight. "No" were the correct answers for statements 9 to 14 . One point was awarded to the respondent's score for every correct answer. Section four was designed to assess respondents' knowledge towards the preventive measures of HIV transmission, which consisted of twelve items. "Yes" were the correct answers for statements one to six. "No" were the correct answers for statements seven to twelve. One point was added to the respondent's score for every correct answer.

Section five was designed to assess respondents' perceptions on the decision in changing therapeutic regimen of HIV-positive patients, which consisted of eight items. Nominal scale "Yes/No" was applied for the respondents to answer the statements in this section. Section six was designed to evaluate the respondents' attitudes towards PLWHA, which consisted of six questions. Nominal scale "Yes/No" was applied for the respondents to answer the statements in this section. For all the statements, every "Yes" contributed one point to the respondent's total scores; while every "No" contributed two points to the respondent's total scores (Khan \& Baig, 2013). The maximum possible score on this section was 12 . Respondents who scored 6 were classified as having positive attitudes towards PLWHA, who scored 7-10 were classified as having negative attitudes towards PLWHA, and who scored 11-12 were classified as having very negative attitudes towards PLWHA (Khan \& Baig, 2013)

\section{Statistical analysis}

Data were cleared and analysed using IBM SPSS version 20.0 (IBM Corp, Armonk, NY). KolmogorovSmirnov test was used to determine the normality of analysed data, with $p>0.05$ were considered as normally distributed. As all the numerical data were not normally distributed, the numerical variables were presented as median and interquartile range (IQR). Categorical data were presented as frequency and percentage. The demographic information and response statements were analysed by using descriptive statistics. Logistic regression was used to explore the independent factors contributed to attitudes of pharmacists towards PLWHA. The variables with $p<0.200$ in simple logistic regression were included into the variable selection for multiple logistic regression model. All the tests were two sided and $p<0.05$ were considered as statistically significant.

\section{Results}

A total of 170 pharmacists $(79.1 \%$ of the recommended minimum sample size) completed the questionnaire with a response rate of $42 \%$. The baseline demographic data of respondents participated in this study are summarised in Table 1. More than half of the respondents were aged 24-30 years old $(57.1 \%)$. Majority of the respondents were females (78.8\%). Most of respondents were Malay (92.4\%). Almost one-third of the respondents had job experience of 4-7 years (37.1\%), and almost two-thirds of the respondents 
encountered 1-20 patients in the past twelve months $(62.4 \%)$. Most of the respondents worked in government hospitals $(61.2 \%)$.

Table 1: Demographic data of study respondents

\begin{tabular}{|c|c|}
\hline Demographic Data $(N=170)$ & $n(\%)$ \\
\hline \multicolumn{2}{|l|}{ Age (years) } \\
\hline $\begin{array}{l}21-30 \\
31-40 \\
41-50 \\
51-60\end{array}$ & $\begin{array}{l}97(57.1) \\
60(35.3) \\
11(6.5) \\
2(1.1)\end{array}$ \\
\hline \multicolumn{2}{|l|}{ Gender } \\
\hline $\begin{array}{l}\text { Male } \\
\text { Female }\end{array}$ & $\begin{array}{l}36(21.2) \\
134 \\
(78.8)\end{array}$ \\
\hline \multicolumn{2}{|l|}{ Race } \\
\hline $\begin{array}{l}\text { Malay } \\
\text { Chinese } \\
\text { Indian } \\
\text { Others }\end{array}$ & $\begin{array}{l}157 \\
(92.4) \\
11(6.5) \\
0(0.0) \\
2(1.1)\end{array}$ \\
\hline \multicolumn{2}{|l|}{ Academic Qualification } \\
\hline $\begin{array}{l}\text { Bachelor } \\
\text { Master }\end{array}$ & $\begin{array}{l}159 \\
(93.5) \\
11(6.5)\end{array}$ \\
\hline \multicolumn{2}{|l|}{ Job Experience } \\
\hline $\begin{array}{l}<1 \text { year } \\
1-3 \text { years } \\
4-7 \text { years } \\
8-11 \text { years } \\
12-14 \text { years } \\
>14 \text { years }\end{array}$ & $\begin{array}{l}14(8.2) \\
37(21.8) \\
63(37.1) \\
25(14.7) \\
13(7.6) \\
18(10.6)\end{array}$ \\
\hline
\end{tabular}

Number of HIV patients encountered for the past 12 months

$\begin{array}{ll}\text { None } & 39(22.9) \\ 1-20 \text { patients } & 106 \\ & (62.4) \\ 21-50 \text { patients } & 14(8.2) \\ >50 \text { patients } & 11(6.5)\end{array}$

Place of Practice

Government Hospital

104

Government Health Clinic

(61.2)

$43(25.3)$

Pharmaceutical Services Division

$10(5.9)$

Community Pharmacy

$9(5.3)$

Academic Institution

2 (1.1)

$1(0.6)$

Private Clinic/ Hospital

$1(0.6)$

\section{Pharmacists' general knowledge about HIV/AIDS}

It was revealed that $87.6 \%$ of the respondents were aware of the abbreviation of AIDS, $98.8 \%$ agreed that HIV is a contagious disease, and $95.9 \%$ of the respondents understood that HIV/AIDS is unable to be cured at this moment.

\section{Pharmacists' knowledge towards the causes and preventive measures of HIVIAIDS}

Majority of the respondents aware of the potential causes [Median (IQR) score $=13.00$ (1.0); maximum score $=14.00]$ and preventive measures [Median (IQR) score $=$ 12.00 (1.0); maximum score $=12.00]$ of HIV/AIDS transmission. The respondents showed most erroneous perceptions on the causes of HIV through kissing an HIVinfected person $(31.8 \%)$, followed by tattoo or body piercing $(27.6 \%)$, and breast-feeding from an HIV-infected mother (26.5\%) (Table 2).

One-sixth of the respondents believed that treating sexually transmitted diseases (STDs) promptly did not prevent transmission of HIV (14.1\%), and $10.6 \%$ of respondents believed that avoiding mosquitoes' bites can prevent transmission of HIV (Table 3).

Table 2: Pharmacists' knowledge towards the possible causes of HIV infection

\begin{tabular}{|c|c|}
\hline Statements & $\begin{array}{l}\text { Correctly } \\
\text { Answered, } n(\%)\end{array}$ \\
\hline $\begin{array}{l}\text { Sexual intercourse without a condom } \\
\text { with HIV-infected person }\end{array}$ & $166(97.7)$ \\
\hline $\begin{array}{l}\text { Sharing needle with HIV-infected } \\
\text { person }\end{array}$ & $169(99.4)$ \\
\hline $\begin{array}{l}\text { Transfusion of HIV-infected blood } \\
\text { or receiving HIV-infected organ }\end{array}$ & $169(99.4)$ \\
\hline $\begin{array}{l}\text { Having sex with multiple sexual } \\
\text { partners with unknown HIV status }\end{array}$ & $167(98.2)$ \\
\hline $\begin{array}{l}\text { From an HIV positive mother to her } \\
\text { foetus }\end{array}$ & $160(94.1)$ \\
\hline $\begin{array}{l}\text { Sharing personal items such as } \\
\text { shaving blades }\end{array}$ & $141(82.9)$ \\
\hline $\begin{array}{l}\text { Breast-feeding from an HIV-infected } \\
\text { mother }\end{array}$ & $125(73.5)$ \\
\hline Having tattoo or body piercing & $123(72.4)$ \\
\hline $\begin{array}{l}\text { Kissing an HIV-infected person } \\
\text { [mouth to mouth/ French kissing] }\end{array}$ & $116(68.2)$ \\
\hline Mosquito bites & $156(91.8)$ \\
\hline $\begin{array}{l}\text { Sharing/ eating a meal with an HIV- } \\
\text { infected person }\end{array}$ & $158(92.9)$ \\
\hline Using a public swimming pool & $166(97.7)$ \\
\hline By using a public toilet & $168(98.8)$ \\
\hline $\begin{array}{l}\text { Casual contacts (hugging or } \\
\text { touching) with an HIV-infected } \\
\text { person }\end{array}$ & $167(98.2)$ \\
\hline
\end{tabular}


Table 3: Pharmacists' knowledge towards the preventive measures of HIV infection

\begin{tabular}{ll}
\hline Statements & $\begin{array}{l}\text { Correctly } \\
\text { Answered, } n \\
(\%)\end{array}$ \\
\hline $\begin{array}{l}\text { Avoid taking illicit drugs/use of } \\
\text { intravenous drug }\end{array}$ & $158(92.9)$ \\
$\begin{array}{l}\text { By avoiding sharing needles and } \\
\text { syringes }\end{array}$ & $170(100.0)$ \\
$\begin{array}{l}\text { Having sex with only one faithful, } \\
\text { uninfected partner }\end{array}$ & $167(98.2)$ \\
$\begin{array}{l}\text { Using condoms during sexual } \\
\text { intercourse }\end{array}$ & $167(98.2)$ \\
$\begin{array}{l}\text { Treating STDs promptly } \\
\text { Screening donated blood before } \\
\text { transfusion }\end{array}$ & $146(85.9)$ \\
$\begin{array}{l}\text { Not sharing swimming pools or toilet } \\
\text { with an infected person }\end{array}$ & $157(92.4)$ \\
$\begin{array}{l}\text { Not sharing food with an infected } \\
\text { person }\end{array}$ & $158(92.9)$ \\
$\begin{array}{l}\text { Isolating people living with } \\
\text { HIV/AIDS }\end{array}$ & $164(96.5)$ \\
$\begin{array}{l}\text { Do not stay with infected person in the } \\
\text { same house }\end{array}$ & $164(96.5)$ \\
$\begin{array}{l}\text { Do not have casual contact with } \\
\text { infected person } \\
\text { Avoiding mosquito bites }\end{array}$ & $163(95.9)$ \\
\hline
\end{tabular}

\section{Pharmacists' perceptions towards the decision to change treatment regimen for HIV/AIDS patients}

The median (IQR) score of respondents on decision to change regimens were 7.00(2.0) [maximum score $=8.00$ ]. Nearly all respondents agreed that treatment regimen should be changed when patient is unable to tolerate adverse reactions of the regimen (97.1\%), and when HIVviral load increases (95.3\%). Two-fifth of the respondents thought that the treatment regimen should not be switched based on the factor that the patient could not afford the treatment cost (40.6\%) (Table 4).

\section{Pharmacists' attitudes towards people living with HIVIAIDS}

Two-thirds of the respondents had negative $(61.8 \%)$ and very negative attitudes (5.3\%) towards PLWHA (Figure 1), with median (IQR) score $=8.00(3.0)$ [maximum score $=12.00$ ]. Half of the respondents revealed that they were not willing to live with HIV/AIDSpositive people in the same house $(51.8 \%)$. Almost twofifth of the respondents were not willing to take care of HIV/AIDS-positive patients (41.2\%). About one-third of the respondents confessed that they did not feel comfortable working together with a colleague who is HIV-positive (31.2\%) (Table 5).
Table 4: Pharmacists' perceptions towards the decision to change treatment regimen for HIV/AIDS patients

\begin{tabular}{ll}
\hline Statements & $\begin{array}{l}\text { Yes, } n \\
(\%)\end{array}$ \\
\hline Patient's compliance is poor & $\begin{array}{l}154 \\
(90.6)\end{array}$ \\
Patient cannot tolerate adverse reactions of & 165 \\
the regimen & $(97.1)$ \\
Viral load increases & 162 \\
& $(95.3)$ \\
CD4 T-cell count decreases & 144 \\
& $(84.7)$ \\
Patient experiences opportunistic infections & 143 \\
& $(84.1)$ \\
Drug interactions with other medicines & 160 \\
& $(94.1)$ \\
Patient cannot afford the treatment cost & 101 \\
& $(59.4)$ \\
Patient is found to be pregnant & 146 \\
& $(85.9)$ \\
\hline
\end{tabular}

Table 5: Pharmacists' attitudes towards people living with HIV/AIDS

\begin{tabular}{ll}
\hline Statements & $\begin{array}{l}\text { Yes, } n \\
(\%)\end{array}$ \\
\hline $\begin{array}{l}\text { Do you feel comfortable about counselling } \\
\text { HIV/AIDS patients? }\end{array}$ & $\begin{array}{l}135 \\
(79.4)\end{array}$ \\
Do you feel comfortable to work together & 117 \\
with a colleague who is a HIV/AIDS patient? & $(68.8)$ \\
\hline Are you willing to live with people having & 82 \\
HIV/AIDS in the same house? & $(48.2)$ \\
Do you feel empathetic towards people living & 161 \\
with HIV and AIDS? & $(94.7)$ \\
Are you willing to take care of patients who & 100 \\
have HIV/AIDS? & $(58.8)$ \\
Do HIV/AIDS patients deserve free & 133 \\
treatment? & $(78.2)$ \\
\hline
\end{tabular}

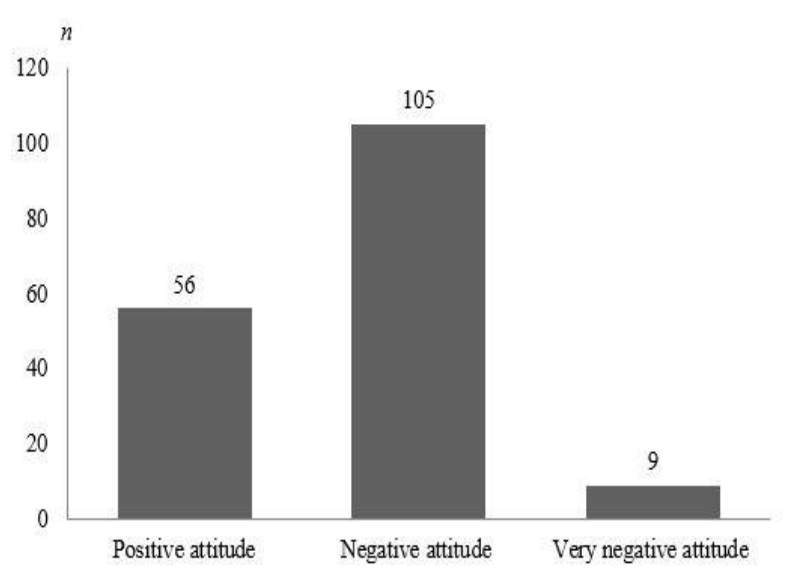

Figure 1: Pharmacists' attitudes towards PLWHA 
Multivariate logistic regression was performed to identify the significant independent factors associated with respondents' negative attitudes towards PLWHA (Table 6). Respondents worked at community pharmacies were 0.87 times less likely to have negative attitudes towards PLWHA than respondents who practiced in other workplaces (Adj OR=0.125; 95\% $\mathrm{CI}=0.025-0.623 ; p=0.011$ ).

\section{Discussion}

In the general knowledge assessment section, the potential of HIV transmission through kissing is the most misunderstood. This trend of misconceptions were similar to the study by Khan and Baig (2013) where up to $89.3 \%$ of respondents believe that kissing HIV-infected person contributed to HIV transmission. WHO stated that "HIV can be transmitted through the exchange of body fluids from infected people, such as blood, breast milk, semen, and vaginal secretions. Individuals cannot become infected through kissing, hugging, shaking hands, or sharing personal objects, food or water" (World Health Organisation, 2019). The hypotonicity of saliva is believed to be protective against HIV transmission by inactivating HIV-transmitting leucocytes, preventing attachment of the HIV-transmitting leucocytes to the mucosal epithelial cells, and lastly HIV production (Baron, Poast, \& Cloyd, 1999).

Another highly prevalent misconception on HIV prevention among recruited respondents is that HIV cannot be prevented by treating sexually transmitted diseases (STDs) promptly. This is different from the findings of Khan and Baig (2013), where most pharmacists' misconception was avoiding taking illicit drug/ use of intravenous drug to prevent HIV transmission. Nevertheless, up to $29.3 \%$ of respondents in Kedah also believed that treating STDs promptly will not prevent HIV transmission (Khan \& Baig, 2013). The risk of HIV transmission through sexual contact were reported to increase by five-to-ten folds in people with ulcerative STDs (Sahasrabuddhe \& Vermund, 2007). Disruption of the integrity of epithelial mucosa by ulcerative STDs, facilitates the contact of HIV with lymphatic and circulatory systems (Cohen, 2004; Wasserheit, 1992). For inflammatory and exudative STDs, the risk of HIV transmission through sexual transmission is increased by two-to-five folds (Sahasrabuddhe \& Vermund, 2007), as the infection and inflammation is associated with recruitment of urethral or cervical discharge filled with HIV-susceptible leucocytes in large volume (Cohen, 2004; Wasserheit, 1992). Management of STDs was reported to achieve reduction of $38 \%$ in incidence of HIV-infection in Tanzania over two years period (Grosskurth et al., 1995). Another study in Malawi had also shown that treatment of STDs reduced the genital tract HIV-viral loads, thereby leading to infectiousness index reduction and lowering of transmission probability (Cohen et al., 1997).
Most respondents agreed that the treatment regimen of HIV/AIDS patients should be modified only in the event of intolerable adverse reactions. Again, our finding is consistent with the earlier study conducted by Khan and Baig (2013). In instances of moderate to severe adverse events, the Malaysian Consensus Guidelines on Antiretroviral Therapy 2017 (Malaysian Society for HIV Medicine, 2017) recommend substituting the causative drug with another of the same ART class, but of different toxicity profile. In our study, we also found that the statement that most respondents disagreed on was changing of treatment regimen is necessary if the patients were unable to afford the treatment cost. In the study by (Khan \& Baig, 2013), it was found that up to three-quarter of respondents did not agree to change treatment regimen on the grounds of treatment cost. However, cost of medication is a true obstacle in HIV treatment and medication adherence as reported in a qualitative study conducted in South Africa (Hardon et al., 2006). In a metaanalysis, Ivers, Kendrick, \& Doucette (2005) found cost of treatment to be an important determinant of adherence towards ARTs in resource-poor settings. These studies provide insights that cost of treatment should be considered when deciding on treatment regimen. In Malaysia, HIV-positive patients who seek treatment in government healthcare facilities have free access to firstline ARTs. In the state of Kelantan, the free-of-charge treatments are extended to alternative choices or secondline treatments. Therefore, the affordable healthcare system in Malaysia may have led to the local practicing pharmacists to have such perceptions on treatment costs.

We found that two-thirds of the respondents in Kelantan had negative attitudes towards PLWHA, similar to the findings in the study by Khan and Baig (2013), which reported that a majority of the hospital pharmacists in Kedah also had negative attitudes towards PLWHA. Discriminatory attitudes of pharmacist against PLWHA were also being reported in Nigeria (Ubaka, Adibe, \& Ukwe, 2014). Nevertheless, pharmacists in Iraq showed positive attitude towards PLWHA in providing care and treatment (Allela, Shareef, \& Ismael, 2017). We observed that our respondents were reluctant to have social and casual contact with PLWHA, but generally had empathy towards them. Despite having high scores of knowledge in the causes and preventive measures of HIV/AIDS, and awareness that casual and social contact with PLWHA will not cause HIV transmission, the respondents were unable to apply their theoretical knowledge in daily practices towards PLWHA with negative attitudes. In fact, we found that there was no significant association between knowledge scores and attitudes towards PLWHA in this study. This finding is in contrast to another study by Balfour et al. (2010) which reported that pharmacists and health science students with better HIV knowledge were associated with lower HIV stigma in South America. 
Table 6: Independent factors affecting pharmacists' attitudes towards people living with HIV/AIDS

\begin{tabular}{|c|c|c|c|c|c|c|}
\hline \multirow[t]{2}{*}{ Variables } & \multirow{2}{*}{$\begin{array}{c}\text { Positive } \\
\begin{array}{c}(n=56) \\
n(\%)\end{array}\end{array}$} & \multirow{2}{*}{$\begin{array}{c}\text { Negative } \\
(n=114) \\
n(\%)\end{array}$} & \multicolumn{2}{|c|}{ Univariate Logistic Regression } & \multicolumn{2}{|c|}{ Multivariate Logistic Regression } \\
\hline & & & OR $(95 \% \mathrm{CI})$ & $p$ value & Adj OR $(95 \%$ CI) & $p$ value \\
\hline \multicolumn{7}{|l|}{ Age (years) } \\
\hline $21-30$ & $28(50.0)$ & $69(60.5)$ & $1.533(0.805-2.921)$ & 0.194 & - & - \\
\hline $31-40$ & $21(37.5)$ & $39(34.2)$ & $0.936(0.479-1.829)$ & 0.847 & - & - \\
\hline $41-50$ & $6(10.7)$ & $5(4.4)$ & $0.495(0.137-1.792)$ & 0.284 & - & - \\
\hline $50-60$ & $1(1.8)$ & $1(0.9)$ & $0.515(0.032-8.398)$ & 0.641 & - & - \\
\hline \multicolumn{7}{|l|}{ Gender } \\
\hline Male & $11(19.7)$ & $25(21.9)$ & $1.149(0.519-2.544)$ & 0.732 & - & - \\
\hline Female & $45(80.3)$ & $89(78.1)$ & $0.870(0.393-1.926)$ & 0.732 & - & - \\
\hline \multicolumn{7}{|l|}{ Race } \\
\hline Malay & $50(89.3)$ & $107(93.8)$ & $1.834(0.586-5.741)$ & 0.297 & - & - \\
\hline Chinese & $4(7.1)$ & $7(6.2)$ & $0.545(0.174-1.706)$ & 0.297 & - & - \\
\hline \multicolumn{7}{|c|}{ Academic Qualification } \\
\hline Degree & $53(94.6)$ & $106(92.9)$ & $1.333(0.340-5.233)$ & 0.680 & - & - \\
\hline Master & $3(5.4)$ & $8(7.1)$ & $0.750(0.191-2.943)$ & 0.680 & - & - \\
\hline \multicolumn{7}{|c|}{ Job Experience (years) } \\
\hline$<1$ & $2(3.6)$ & $12(10.5)$ & $3.176(0.686-14.71)$ & 0.139 & - & - \\
\hline $1-3$ & $10(17.8)$ & $27(23.7)$ & $1.359(0.604-3.061)$ & 0.459 & - & - \\
\hline $4-7$ & $24(42.9)$ & $39(34.2)$ & $0.693(0.360-1.336)$ & 0.274 & - & - \\
\hline $8-11$ & $7(12.5)$ & $18(15.8)$ & $1.312(0.514-3.355)$ & 0.574 & - & - \\
\hline $11-13$ & $3(5.4)$ & $10(8.8)$ & $1.679(0.448-6.425)$ & 0.436 & - & - \\
\hline$>14$ & $10(17.8)$ & $8(7.0)$ & $0.347(0.129-0.936)$ & 0.037 & - & - \\
\hline
\end{tabular}




\begin{tabular}{|c|c|c|c|c|c|c|}
\hline \multirow[t]{2}{*}{ Variables } & \multirow{2}{*}{$\begin{array}{l}\text { Positive } \\
\begin{array}{c}(n=56) \\
n(\%)\end{array}\end{array}$} & \multirow{2}{*}{$\begin{array}{l}\text { Negative } \\
\begin{array}{c}(n=114) \\
n(\%)\end{array}\end{array}$} & \multicolumn{2}{|c|}{ Univariate Logistic Regression } & \multicolumn{2}{|c|}{ Multivariate Logistic Regression } \\
\hline & & & OR $(95 \% \mathrm{CI})$ & $p$ value & Adj OR $(95 \% \mathrm{CI})$ & $p$ value \\
\hline \multicolumn{7}{|l|}{ Place of Practice } \\
\hline Government Hospital & $28(50.0)$ & $76(66.7)$ & $2.000(1.041-3.841)$ & 0.037 & - & - \\
\hline Government Health Clinic & $16(28.6)$ & $27(23.7)$ & $0.848(0.408-1.764)$ & 0.660 & - & - \\
\hline Pharm. Service Division & $3(5.4)$ & $7(6.1)$ & $0.981(0.236-4.078)$ & 0.979 & - & - \\
\hline Community Pharmacy & $7(12.5)$ & $2(1.7)$ & $0.125(0.025-0.623)$ & 0.011 & $0.125(0.025-0.623)$ & 0.011 \\
\hline Academic Institution & $2(3.5)$ & $0(0.0)$ & - & $>0.999$ & - & - \\
\hline Private Hospital/ Clinic & $0(0.0)$ & $1(0.9)$ & - & $>0.999$ & - & - \\
\hline Pharm. Industrial & $0(0.0)$ & $1(0.9)$ & - & $>0.999$ & - & - \\
\hline \multicolumn{7}{|l|}{ No of HIV patients encountered past 1 year } \\
\hline \multicolumn{7}{|l|}{ None } \\
\hline $1-20$ & $12(21.4)$ & $27(23.7)$ & $1.138(0.527-2.459)$ & 0.742 & - & - \\
\hline $21-50$ & $35(62.5)$ & $71(62.3)$ & $0.991(0.512-1.918)$ & 0.978 & - & - \\
\hline \multirow{2}{*}{$>50$} & $5(9.0)$ & $9(7.9)$ & $0.874(0.279-2.743)$ & 0.818 & - & - \\
\hline & $4(7.1)$ & $7(6.1)$ & $0.850(0.238-3.036)$ & 0.803 & - & - \\
\hline Knowledge of HIV/AIDS [median (IQR)] & $24.00(2)$ & $24.00(2)$ & $0.862(0.703-1.056)$ & 0.152 & - & - \\
\hline Knowledge on causes of HIV/AIDS [median (IQR)] & $12.50(1)$ & $13.00(2)$ & $0.861(0.641-1.156)$ & 0.319 & - & - \\
\hline Knowledge on preventive measures of HIV/AIDS [median (IQR)] & $12.00(1)$ & $12.00(1)$ & $0.788(0.559-1.111)$ & 0.788 & - & - \\
\hline
\end{tabular}


Here, it seems that education on scientific matters may not be sufficient to achieve practices changes, and that attitudes and cultural beliefs should also be addressed in future educational programs (Reis et al.,2005).

HIV-related discriminations and its related problems is prevalent throughout the world, especially in developing countries with rich cultural, moral, and religious values such as Malaysia. HIV/AIDS cases were often thought to be linked to moral improprieties, such as drug use, prostitution, heterosexual promiscuity, and homosexual behaviour. HIV is also believed to be highly contagious and may pose a threat to the community (Wong \& Nur Syuhada, 2011). The life-threatening nature of HIV/AIDS may also lead to the negative attitudes among pharmacists towards PLWHA (Allela et al., 2017). In addition, as majority of our respondents were Malays, and up to $68.2 \%$ $(n=107)$ of the Malays had negative attitude towards PLWHA, these negative attitudes may be associated with cultural-related conception. The burial rite of Muslim is done with bleach for known HIV-infected people, which may reinforce the societal stigma and individual anxiety towards PLWHA (Fadzil, Othman, \& Mustafa, 2016). With these concerns, our respondents may refuse to take any unnecessary risks that may expose oneself in HIV transmission risk through accidental injuries or accidental transmission of infected body fluids through daily contact.

In this study, respondents working in community pharmacies had significant positive attitudes towards PLWHA. In the study that only focused in hospital pharmacists, Khan and Baig (2013) reported that $86.6 \%$ of the hospital pharmacists in Kedah had negative attitudes towards PLWHA, but the reasons for such findings were not further investigated. A study conducted among community pharmacists in India by Gupta et al. (2010) found that majority of the pharmacists had senses of professional obligation towards PLWHA and were not worried about potential HIV exposure during medications dispensing to HIV-positive patients. However, the surveyed community pharmacists were not actively involved in HIV services as about two-thirds of pharmacists revealed that they did not frequently encountered HIV-positive patients (Gupta et al., 2010). This similar situation may occur in our community pharmacy settings, where there is minimal involvement of the community pharmacists in providing care towards PLWHA, as most of the HIV-positive patients were managed in hospitals. As most of the HIV/AIDS patients with presence of opportunistic infections were treated in hospitals, this may have led to the fear of hospital pharmacists in contacting with HIV/AIDS patients compared to the community pharmacists, for example concerns for risk of exposure to contagious opportunistic infections such as occupationally-acquired tuberculosis (Engelbrecht et al., 2019).
There are some limitations and bias in this study. Some degree of social desirability bias, which may affect participants' response according to ethics of pharmacy practices, may be present in our study. The environment to complete the questionnaires were beyond our control. We were also unable to ensure that the respondents did not search for references to answer the questionnaires, or whether their responses were influenced by peers when answered in groups. A positive response bias is also likely to be present, as pharmacists with more knowledge on HIV/AIDS were more likely to fill in the questionnaire, which may yield non-representative high scores (Domnich et al., 2015). As the number of respondents included in this study were unable to achieve the recommended sample size, our results may not statistically represent the pharmacist population in Kelantan. Lastly, this study was conducted in Kelantan, which made up $10.3 \%$ of the national HIV population (Ministry of Health Malaysia, 2018); free ARTs were provided to all HIV-positive patients; lesser distribution of community pharmacies compared to other states (Pharmaceutical Services Division Ministry of Health Malaysia, 2011); and due to inherent geographical distribution of the Malay race, there were also more Malay pharmacists in the state, as reflected in the high proportion in the study respondents. Hence, the findings on this study may not necessarily be generalizable to other regions and settings in Malaysia. Further studies may also be expanded to the whole Malaysia to identify the pharmacists' knowledge, perception and attitudes towards PLWHA in Malaysia.

In the future, education and sharing sessions may be carried out to enhance the pharmacists' knowledge on HIV/AIDS, focusing on the common misconceptions. As pharmacists' high knowledge scores on causes and prevention of HIV/AIDS were not associated with the high rates of negative attitudes, it is important to investigate further the concerns of the pharmacists towards PLWHA. As stigma and discrimination reduces the quality of treatment (Yang, Zhang, Chan, \& Reidpath, 2005) and affect the self-esteem of HIV-positive patients (Surlis \& Hyde, 2001), efforts to assist pharmacists in overcoming their uneasiness when dealing with PLWHA will contribute positively towards future HIV disease control strategies.

\section{Conclusion}

In conclusion, several key misconceptions towards the causes of HIV/AIDS, preventive measures of HIV/AIDS transmission, and the necessity in changing treatment regimen when needed were identified among pharmacists in Kelantan, Malaysia. Despite having good disease related knowledge, most pharmacists in Kelantan present negative attitudes towards PLWHA while working in a community setting was significantly associated with more positive attitudes. Future studies should identify the causes of such 
negative attitudes; and feed educational program strategies as part of the efforts to improve existing disease management measures attitudes.

\section{Acknowledgements}

We thank the Director of Health Malaysia for permission to publish this paper; Ms Lim Xin Yi, Institute for Medical Research, for guiding and proof-reading the article; Pharmaceutical Service Division of Kelantan, Ms Azura binti Musa, and Ms Noraniza binti Mohamad Zalik for delivering help in distribution online questionnaire; Ms Siti Nurul Zuliana binti Abdullah for reviewing the online questionnaire.

\section{Conflict of Interest}

None.

\section{References}

Allela, O. Q. B., Shareef, N. S., \& Ismael, B. S. (2017). Acquired immunodeficiency syndrome and human immunodeficiency virus knowledge, attitude, and perception among pharmacists in Erbil, Kurdistan Region, Iraq. Journal of Basic and Clinical Pharmacy, 8(S2), S74-S79.

Balfour, L., Corace, K., Tasca, G. A., Best-Plummer, W., MacPherson, P. A., \& Cameron, D. W. (2010). High HIV knowledge relates to low stigma in pharmacists and university health science students in Guyana, South America. International Journal of Infectious Diseases, 14(10), e881-e887. doi:10.1016/j.ijid.2010.03.021

Baron, S., Poast, J., \& Cloyd, M. (1999). Why is HIV rarely transmitted by oral secretions? Saliva can disrupt orally shed, infected leucocytes. Archives of Internal Medicine, 159(3), 303-310. doi:10.1001/archinte.159.3.303

Centers for Disease Control and Preventioin. (2019). HIV stigma and discrimination. Retrieved from https://www.cdc.gov/hiv/basics/hivstigma/index.html

City Population. (2017). Malaysia: Administrative Division. $\quad$ Retrieved from https://www.citypopulation.de/en/malaysia/admin/

Cohen, M. (2004). HIV and sexually transmitted diseases: lethal synergy. Topics in HIV Medicine: a Publication of the International AIDS Society, USA, 12(4), 104107.

Cohen, M. S., Hoffman, I. F., Royce, R. A., Kazembe, P., Dyer, J. R., Daly, C. C., ... Eron Jr, J. J. (1997). Reduction of concentration of HIV-1 in semen after treatment of urethritis: implications for prevention of sexual transmission of HIV-1. AIDSCAP Malawi
Research Group. Lancet, 349(9069), 1868-1873. doi:10.1016/s0140-6736(97)02190-9

Domnich, A., Panatto, D., Signori, A., Bragazzi, N. L., Cristina, M. L., Amicizia, D., \& Gasparini, R. (2015). Uncontrolled web-based administration of surveys on factual health-related knowledge: a randomized study of untimed versus timed quizzing. Journal of Medical Internet Research, 17(4), e94. doi:10.2196/jmir.3734

Engelbrecht, M., Rau, A., Kigozi, G., van Rensburg, A. J., Wouters, E., Sommerland, N., ... Uebel, K. (2019). Waiting to inhale: factors associated with healthcare workers' fears of occupationally-acquired tuberculosis (TB). BMC Infectious Diseases, 19, 475. doi:10.1186/s12879-019-4115-z

Fadzil, N. A., Othman, Z., \& Mustafa, M. (2016). Stigma in Malay patients with HIV/AIDS in Malaysia. International Medical Journal, 23(4), 324-327. doi: $10.5281 /$ zenodo. 2588307

Grosskurth, H., Mosha, F., Todd, J., Mwijarubi, E., Klokke, A., Senkoro, K., ... Ka-Gina, G. (1995). Impact of improved treatment of sexually transmitted diseases on HIV infection in rural Tanzania: randomised controlled trial. Lancet, 346(8974), 530536. doi:10.1016/s0140-6736(95)91380-7

Gupta, A., Sane, S. S., Gurbani, A., Bollinger, R. C., Mehendale, S. M., \& Godbole, S. V. (2010). Stigmatizing attitudes and low levels of knowledge but high willingness to participate in HIV management: a community-based survey of pharmacies in Pune, India. BMC Public Health, 10, 517. doi:10.1186/1471-2458-10-517

Hardon, A., Davey, S., Gerrits, T., Hodgkin, C., Irunde, H., Kgatlwane, J., ... Laing, R. (2006). From access to adherence: the challenges of antiretroviral treatment: Studies from Botswana, Tanzania and Uganda 2006. World Health Organisation. Retrieved from https://apps.who.int/iris/handle/10665/43522

Ivers, L. C., Kendrick, D., \& Doucette, K. (2005). Efficacy of antiretroviral therapy programs in resource-poor settings: a meta-analysis of the published literature. Clinical Infectious Diseases, 41(2), 217-224. doi:10.1086/431199

Khan, T. M., \& Baig, M. R. (2013). Hospital pharmacists' knowledge about and attitude toward HIV/AIDS and patients living with HIV/AIDS in Kedah, Malaysia. Archives of Medical Science, 9(6), 1117-1124. doi:10.5114/aoms.2012.30953

Malaysian Society for HIV Medicine. (2017). Malaysian consensus guidelines on antiretroviral therapy 2017. Ministry of Health Malaysia. 
Ministry of Health Malaysia. (2015). National strategic plan for ending AIDS 2016-2030. Retrieved from http://vlib.moh.gov.my/cms/documentstorage/com.t ms.cms.document.Document f4ad1ba5-a0188549d7eb9d00-8579b30f/spl-aids2016-2030.pdf

Ministry of Health Malaysia. (2018). Country progress report on HIV/AIDS 2018. Retrieved from https://www.moh.gov.my/index.php/

Paterson, D. L., Swindells, S., Mohr, J., Brester, M., Vergis, E. N., Squier, C., ... Singh, N. (2000). Adherence to protease inhibitor therapy and outcomes in patients with HIV infection. Annals of Internal Medicine, 133(1), 21-30. doi:10.7326/0003-4819133-1-200007040-00004

Pharmaceutical Services Division Ministry of Health Malaysia. (2011). Bilangan farmasi komuniti di Malaysia mengikut negeri. Retrieved from https://www.pharmacy.gov.my/v2/ms/content/bilanga n-farmasi-komuniti-malaysia-mengikut-negeri.html

Pharmaceutical Services Division Ministry of Health Malaysia. (2014). Protocol Medication Therapy Adherence Clinic: Retroviral Disease (Adult \& Paediatric) (2nd ed.). Retrieved from https://www.pharmacy.gov.my/v2/sites/default/files/d ocument-upload/protocol-mtac-rvd-fa-ver2.pdf

Pudpong, N., Chariyalertsak, S., Prakongsai, P., Srithanaviboonchai, K., Thongsomsawadhi, K., Wongthanee, A., ... Smutraprapoot, P. (2014). Report of a pilot: Developing tools and methods to measure HIV-related stigma \& discrimination in health care settings in Thailand. Thailand: International Health Policy Program, Ministry of Public Health Thailand. Retrieved from https://www.researchgate.net/publication/299363911 _Developing_tools_and_methods_to_measure_HIVrelated_stigma_discrimination_in_health_care_settin gs_in_Thailand

Reis, C., Heisler, M., Amowitz, L. L., Moreland, R. S., Mafeni, J. O., Anyamele, C., \& Iacopino, V. (2005). Discriminatory attitudes and practices by health workers toward patients with HIV/AIDS in Nigeria. PLoS Medicine, 2(8), e246. doi:10.1371/journal.pmed.0020246
Sahasrabuddhe, V. V., \& Vermund, S. H. (2007). The future of HIV prevention: STI control and circumcision interventions. Infectious Disease Clinics of North America, 21(1), 241-251. doi:10.1016/j.idc.2007.03.005

Schaecher, K. L. (2013). The importance of treatment adherence in HIV. American Journal of Managed Care, 19 (12 Suppl), s231-237.

Surlis, S., \& Hyde, A. (2001). HIV-positive patients' experiences of stigma during hospitalization. Journal of the Association of Nurses in AIDS Care, 12(6), 6877. doi:10.1016/S1055-3290(06)60185-4

Tseng, A., Foisy, M., Hughes, C. A., Kelly, D., Chan, S., Dayneka, N., ... Yoong, D. (2012). Role of the pharamacist in caring for patients with HIV/AIDS: clinical practice guidelines. The Canadian Journal of Hospital Pharmacy, 65(2), 125-145. doi:10.4212/cjhp.v65i2.1120

Ubaka, C., Adibe, M., \& Ukwe, C. V. (2014). Discriminatory attitudes of pharmacy students and pharmacists against people living with HIV/AIDS. Tropical Journal of Pharmacentical Research, 13(2), 295-302. doi:10.4314/tjpr.v13i2.20

Wasserheit, J. N. (1992). Epidemiological synergy. Interrelationships between human immunodeficiency virus infection and other sexually transmitted diseases. Journal of Sexually Transmitted Diseases, 19(2), 61-77.

Wong, L. P., \& Nur Syuhada, A. R. (2011). Stigmatization and discrimination towards people living with or affected by HIV/AIDS by the general public in Malaysia. The Southeast Asian Journal of Tropical Medicine and Public Health, 42(5), 1119-1129.

World Health Organisation. (2019). HIV/AIDS. Retrieved from https://www.who.int/news-room/factsheets/detail/hiv-aids

Yang, Y., Zhang, K. L., Chan, K. Y., \& Reidpath, D. D. (2005). Institutional and structural forms of HIVrelated discrimination in health care: a study set in Beijing. AIDS Care, 17(Suppl 2), S129-140. doi:10.1080/09540120500119874 